\begin{tabular}{lc|c|}
\hline NIPES & Journal of Science and Technology Research & 0 \\
\hline & Journal homepage: www.nipesjournals.org.ng & sience and \\
Technology \\
Research \\
\hline
\end{tabular}

\title{
A Review of Solid Waste Management Practice in Nigeria
}

\author{
${ }^{1}$ Ukala, D.C., ${ }^{2}$ Akaun Ifeanyi, H. I. ${ }^{3 *}$ Owamah \\ ${ }^{1 \& 3}$ Department of Civil Engineering, Delta State University, Abraka, Oleh Campus, PMB 1, Nigeria \\ ${ }^{2}$ Department of General Studies, Delta State Polytechnic, Ogwashi-Uku, Delta State \\ ${ }^{3}$ owamah.hilary@ gmail.com; ${ }^{3}$ hiowamah@delsu.edu.ng; ${ }^{2}$ ukalachuks@ gmail.com; 2 ifeanyiakaun@ gmail.com;
}

\section{Article Info}

\section{Article history:}

Received 1 July 2020

Revised 13 July 2020

Accepted 29 July 2020

Available online 31 August 2020

Keywords: Solid waste,

Management, Challenges, Nigeria

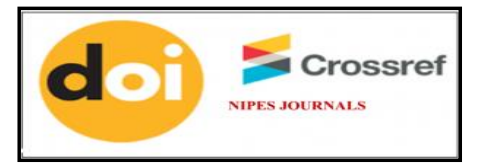

https://doi.org/10.37933/nipes/2.3.2020.17

\begin{abstract}
This paper appraised solid waste management in Nigeria with a view to both identifying the existing solid waste management practices and current challenges. The paper also examined the benefits derivable from the adoption of proper solid waste management techniques. The identified methods of solid waste management are incineration, recycling of waste, landfill, source reduction, composting and avoidance and source reduction methods. The identified challenges include poor funding, poor collection techniques, grossly inadequate collection equipment, reckless disposal of solid waste on the environment, huge increase in population and urbanization and poor government attitude to waste management, and lack of trained/professional waste managers. In the light of the challenges, the paper advocates for the control of urbanization and population growth, increased funding for the management of solid waste and commitment from government among others.
\end{abstract}

https://nipesjournals.org.ng (C) 2020 NIPES Pub. All rights reserved

\section{Introduction}

Environmental challenges arising from improper disposal of solid waste are now major issues in many Nigerian urban cities and rural communities. This is as a result of huge increases in solid waste generation following the increase in population and urbanization [1]. As humans engage in their daily activities to meet up with their basic human needs, a lot of unwanted materials, often referred to as waste, are generated. Wastes generated by homes; industries, organizations, schools and businesses generate wastes that are not properly disposed. Solid wastes which emanate from industrial and residential activities, generally, consist of unused or leftover food, plastic, metal, paper, textile, glass, among others [2].

According to [3], solid wastes are discarded materials, generated from industries, commercial places or homes, which are no longer of any economic value. They could be organic and inorganic materials. On the other hand, [4] viewed solid waste as a resource that should be recycled for further usage rather than being discarded to constitute nuisance. Waste can be domestic or industrial. While domestic solid wastes are generated from homes, industrial wastes are the wastes generated by industries, organizations, schools and businesses. The rate of solid waste generation in Nigeria has increased due to the rapid increase in population, movement of people to metropolitan areas and industrial expansion. The increase in urbanization has made the managing of solid waste in the country more complex. At both local and state levels, and as well as the larger global level, there is 
a continually growing issue of concern on the observed trend of waste accumulation [5] The inability of the Nigerian government to handle generated solid waste has resulted in poor solid-waste management practices [1].

In the opinion of [6], one of the challenges facing urban settlements around the world is the management of solid waste. The environmental challenge faced by cities in Nigeria is due, in part, to the increasing stream of generated solid waste driven by population growth, industrialization and urbanization [7-8] as well as the financial burden of waste management and lack of technical capacity of city authorities [9-10]. Solid waste therefore refers to the organic and inorganic used-up materials that encompass both a heterogeneous mass of wastes (domestic) as well as a more homogeneous accumulation of agricultural, industrial and mineral wastes [11].

Solid waste management involves collection, transportation, and processing, recycling or ultimate disposal. The huge increase in solid waste generation from cities and how to dispose of them have caused serious environmental challenges in developing countries like Nigeria [12]. Waste management needs careful planning, if the desired goals are to be achieved. The management of solid wastes, particularly, those wastes generated in urban areas are increasingly becoming complex [13]. Indiscriminate waste disposal leads to the destruction of the aesthetic beauty of the environment, causes flooding and environmental air pollution [14].

Many lives are also lost annually due to filthy-environment related diseases such as diarrhea, malaria, cholera, diarrhea, typhoid fever, etc. [15]. In Sub-Sahara Africa, solid waste management has become a major social and environmental challenge due to increasing rate of generation and emerging products in the waste stream [15]. The management of solid waste in many African cities and rural communities has been reported to be ineffective [13].

Solid waste generation in a locality is a function of what is produced and consumed in that locality. The complexity of growth in urban settlements in Nigeria in relation to its inhibiting factors has equally complicated the problem of prompt evacuation of solid waste within the urban settlement. The collection and transportation of solid waste are vital aspects in solid waste management systems that bring the waste generators and managers in contact. It is therefore imperative to manage this relationship for effective solid waste control [16]. However, how this contact point can be efficiently managed has not been well studied. Equally, in reality, there, are no provisions for standard waste collection facilities in many Nigerian except the only recently improvised drums. The drums get filled up in no time owing to their limited sizes and spread to litter the immediate environment thereby further worsening environmental condition. With the absence of these standard dumpsters, the residents of the cities resort to dumping of waste on open plots, abandoned buildings, river banks, drainage channels, road divides, etc. These wastes often eventually dissipate into water bodies and pose series of health risks to the people who use the water bodies for domestic purposes.

This practice of indiscriminate dumping of solid waste has the potential of giving rise to water and air pollution, greenhouse gas emission and may give rise to other gases that cause serious problems to the human health and environment [17]. Several waste management practices in the past and present include open dumping, burning, scavenging, separation, recovery, storage, evacuation and recycling. Pivotal to the aforementioned management practices is collection and transportation of solid waste to places where these respective management practices could be enhanced. This prompt transport or movement of solid waste however, could only be effective if solid waste bins are strategically located where they could swiftly and promptly be evacuated. The main aim of this review is to examine solid waste management in Nigeria with respect to the various means of solid waste management in Nigeria, benefits of solid waste management and the challenges confronting solid waste management in the country. 


\section{Some Methods of Solid Waste Management}

\section{There are several methods for solid waste management in our cities as briefly discussed. $i$. Incineration}

This is a disposal approach that involves combustion and subsequent conversion of organic solid wastes into gaseous products and residues [18]. Incineration helps to reduce the volume of solid waste by $30 \%$ of the original volume. Over the years, large and small scale incineration activities have been carried out at industrial and domestic levels respectively. Certain hazardous solid wastes are usually disposed by incineration. All these notwithstanding, incineration has been the subject of controversial scientific discussion as a result of issues relating to the emission of gaseous pollutants into the atmosphere. This method of solid waste management is most common in nations with small landmass, which makes the construction of large scale landfills difficult [19].

\section{ii. $\quad$ Recycling of Waste}

Recycling in solid waste management is the reuse of waste materials through the reprocessing of the materials into new products. The recyclable materials may be collected differently from the others in the waste stream using dedicated waste bins and collection trucks. Sometimes, the generator of the waste is made to separate it into different components and stored in different bins prior to collection [20]. Recycling of wastes consist of finding new ways of using previously discarded materials (wood, glass, plastics, metals, textiles, cardboard, paper, leather, rubber and ceramics and in further production of useable goods [21]. Solid waste recycling is therefore recognized as a tenable solution for cleaning up the cluttered environment. Organic solid wastes can also be recycled into fertilizer for agricultural purposes. Recycling reduces the amount of household solid waste to be collected, transported and disposed [22].

\section{iii. Landfill}

Landfilling involves the burying of solid waste in a well designed and constructed landfill. It is the common practice in many developed nations. Landfilling is one of the most hygienic and cheapest methods of solid waste disposal. It could however still have adverse conditions when it starts aging or if the design and construction was poor. Some of the adverse environmental conditions are the spread of litters by wind, contamination of groundwater by leachate, attraction of rodents etc. Another challenge with the use landfill technique is the emission of methane and carbon dioxide gases, which contribute majorly to greenhouse effect.

\section{iv. Avoidance and Source Reduction Method}

This is believed to be the best option in the waste minimization ladder. It involves the least energy and raw material consumption [23]. One essential aspect of solid waste management is the minimization of generation. Others relating to avoidance are the reuse of products, repairs of broken products rather than buying of new ones, production of refillable or reusable products like plastic bags [23].

\section{v. Composting}

Composting is the process by which solid organic waste is degraded by aerobic, mesophilic and or thermophilic microorganisms. It converts organic waste into stable, sanitary and humus like product, which can be used for soil improvement. The establishment of a composting centre will be a means of transforming a lot of solid waste to composts, which if successfully managed, would reduce the consumption of inorganic fertilizer and results in an enormous savings for the economy [24]. While a high temperature is required for mechanical composting, the common method in rural and suburban communities is the deposition of refuse in dug pits, to rot or ferment. The compost that emanates from this process is used manure in farms [24]. 


\section{Benefits and challenges of proper solid waste management}

\subsection{Benefits}

Wastes are defined as unwanted or unusable items, remains, or byproducts, or household garbage. However, as unwanted as they may be, their importance to man cannot be overestimated when correctly disposed. Solid waste should not be discarded or disposed without recourse to future use. Solid wastes, if managed appropriately through well-articulated policy and practice, could be valuable resources. [25] and [26] identified four benefits including economic, social, environmental and inter-generational equity as briefly explained.

Economic advantage: When markets are established for recyclables, it brings about efficient practices in product design, production and consumption. New jobs also get opened up for the citizens of the country.

Social advantage: The reduction of the negative impact of solid waste on public health as a result of proper management practices can result in more appealing settlements with new sources of employment for the previously impoverished and unemployed people.

Environmental advantage: Removal of the negative effects of waste on the environment can provide improved air and water quality and help in the reduction of greenhouse emissions [24].

Inter-generational equity: Proper managing of solid waste leads to sustainable development and ensure that subsequent generations would still have a robust economy and clean environment [26].

\subsection{Challenges facing Solid Waste Management in Nigeria}

Contrary to practices in the developed nations of total recovery and recycling of solid waste, the challenge of solid waste management in Nigeria is a major source of worry [26]. Some of the challenges facing solid waste management in Nigeria are:

\section{i. $\quad$ Improper collection systems/Inadequate collection equipment and vehicles}

While most local government areas in Nigeria lack the facilities for effective collection and management of solid waste, it is grossly inadequate among the few that have them. This has made most people dump their wastes on the streets as the collectors seldom come to cart away piled up waste. This act defaces the streets and leads to air pollution [27]. Solid waste collection and transportation require a good number of machinery and equipment due to the transportation of the wastes over long distances to dumpsites or treatment area. Hence, if collection equipment and vehicles are not available there is going to be increase in waste in unapproved areas [27].

\section{ii. $\quad$ Indiscriminate dumping of waste}

Most inhabitants across the length and breadth of Nigeria dump their wastes at any location that suits them because there are no defined waste collection points in most Nigerian cities. This creates a collection problem, especially in densely populated and poor planned cities [27].

\section{iii. $\quad$ Poor execution of government policies and lack of continuity}

This is a major challenge in the management of solid waste in Nigeria [27]. Nigeria does not only have weak legislations about solid waste management, enforcement is also weak [28]. This has provided the people the latitude to indiscriminately dispose their solid wastes at unauthorized places.

\section{iv. $\quad$ Population growth and urbanization}

The unprecedented rapid urbanization and urban growth occurring in Nigeria has been identified as one of the critical challenges facing solid waste management in Nigeria and other cities in Africa [29-30]. 


\section{v. $\quad$ Funding}

Another challenge facing solid waste management is funding. There has been a dwindling financial resource allocation for environmental issues. Poor funding is the major problem of solid waste management in Nigeria. The funding problem is basically a problem of poor recovery of investments made on solid waste management and the limited funds of government. The inability to recover funds spent on solid waste management can be attributed to lack of willingness to pay for the service by households. Actualization of solid waste management schemes involves consistent funding [31].

\section{vi. $\quad$ Poor attitude of people on proper disposal of solid wastes}

Another major challenge facing solid waste management in the Nigerian society is the poor waste disposal habit of the people. According to [32], the "government-does-everything" philosophy of many Nigerians is also a major problem to solid waste management in the country. This poor habit has made people to dump refuse indiscriminately on drainages, roads, open spaces, markets, among other places.

\section{vii. $\quad$ Inadequate number of trained personnel}

The number of professionals with requisite knowledge and capability as it relates to solid waste management in Nigeria are few.

\section{Conclusion and Recommendations}

This study has shown that solid waste management in Nigeria is yet to become effective and organized. Poor funding, inadequate facilities and lack of commitment from government were noted to be the major problems. The importance of clean environment to good health cannot be overemphasized. Proper solid waste management, undoubtedly, will promote a clean environment. To achieve this, some of the identified challenges must be succinctly addressed. In this regard, the following recommendations are made:

i. The pattern of urban growth and rapid population explosion in cities should be brought under control. Rural urban migration can be checked by ensuring that rural settlements are adequately restructured through infrastructural developments.

ii. Government needs to ensure that appropriate urban planning measures are put in place to check the uncontrolled and un-coordinated growth of the cities.

iii. Financial resources should be allocated to the various ties of government for the management of solid waste.

iv. The government should carry out enlightenment programme on the proper ways of solid waste disposal and the dangers associated with improper solid waste management to the environment and to health.

\section{References}

[1] Umunna, N.M. (2009). Solid waste generation and disposal in a Nigerian City: An empirical analysis in Onitsha Metropolis. Journal of Environmental Management and Safety, 2 (1), 181-191.

[2] Manaf, L. A., Samah, M. A. A. \& Zukki, N. I. M. (2009). Municipal solid waste management in Malaysia: Practices and challenges. Waste management, 29(11), 2902-2906.

[3] UNICEF (2006). Solid and liquid waste management in rural areas. A Technical Note, 2006.

[4] Nabegu , B.A. (2010). An Analysis of Municipal Solid Waste in Kano Metropolis, Nigeria. Journal of Human Ecology 31 (2), 111-119

[5] Murali, K. G, Lakshmana, D. B, \& Nooka R, K (2014). An appraisal of sustainability scenario of solid waste management: A GIS study on municipal wards of Hyderabad, India”. Journal of Geology and Geosciences.3 (2), 143.doi:10.4172/2329- 6755.1000143

[6] Oyinloye, M.A., (2013). Using GIS and remote sensing in urban waste disposal and management: A focus on Owo L.G.A, Ondo State, Nigeria. European International Journal of Science and Technology. 2304-9693 www.eijst.org.uk

[7] Ahmed, S. A. \& Ali, M. (2004). Partnerships for solid waste management in developing countries: linking theories to realities. Habitat International, 28, 3, 467-479.

[8] Annepu, R. K. (2012). Sustainable solid waste management in India," Columbia University, New York. 
Ukala, D.C. et al. / NIPES Journal of Science and Technology Research 2(3) 2020 pp. 169-174

[9] Henry, R. K. Yongsheng, Z. \& Jun, D. (2006). Municipal solid waste management challenges in developing countries - Kenyan case study. Waste Management, 26(1), 92-100.

[10] Guerrero, L. A., Maas, G. \& Hogland, W. (2013). Solid waste management challenges for cities in developing countries. Waste Management, 33(1), 220-232.

[11] Karsauliya, S. (2013). Application of remote sensing and GIS in solid waste management: A case study of surroundings of River Yamuna, India. International Journal of Environmental Engineering and Management, 4(6), 593-604.

[12] Blight, G.E. \& Mbende, C.M. (1996). Some problems of waste management in developing countries. Journal of Solid Waste Technology and Management, 23(1), 19-27.

[13] Maity, S.K (2014). "Feature Extraction from Waste Generation Map by Applying Squared Error Algorithm Method" Scholars Journal of Engineering and Technology, 2(3) A: 335-338

[14] Iro, S.I., Okorondu, U.V., \& Mbano, E. (2012): Implications of geographic information system in mapping solid waste collection points in Owerri, Imo State". An International Journal of Science and Technology Bahir Dar, Ethiopia, 1(1), 60-69.

[15] Idowu, A. P., Adagunodo, E.A., Esimai, O.A. \& Olopade, T.C. (2012). Development of A Web based GIS waste disposal management system for Nigeria. International Journal of Information, Engineering and Electronic Business. 3, 40-48.

[16] Siddam.S., Khadikar, I. \& Chitade, A. (2012).Route optimization for solid waste management using Geoinformatics. Journal of Mechanical and Civil Engineering. 2(1), 78-83.

[17] Remigios, V. M., \& Wiseman, M. (2012) The Management, Practice and Environmental Health Implications of the Municipal Solid Waste Dump Site in Alice, South Africa. Online Journal of Social Sciences Research. 2277-0844; 1(5), 125-131.

[18] Isa, M.H., Asaari, F.A.H., Ramli, N.A., Ahamad, S., Siew, T.S., (2005). Solid waste collection and recycling in Nibong, Tebal, Penang, Malaysia: a case study. Waste Managt \& Res., 23(6): 565-570.

[19]Fullerton, D., Kinnaman, T., 1995. Garbage, Recycling and Illicit Burning or Dumping. Journal of Environmental Economics and Management 29, 78-91.

[20] Ayotamuno, J.M., \& Gobo, A.E., (2004). Municipal solid waste management in Port Harcourt, Nigeria: Obstacles and prospects. Management and Environmental Quarterly International Journal, 15, 389-398.

[21] Martin, M. (2010): Solid wastes, poverty and the environment in developing country cities: Challenges and opportunities, WIDER Working Paper, No. 2010/23, ISBN 978-92-9230-258-0, The United Nations University World Institute for Development Economics Research (UNU-WIDER), Helsinki

[22] Asante, J. (2016). Assessment of household solid waste management practices in the Sunyani West District of Ghana. An Unpublished Master of Public Health Degree, University of Ghana, Legon. Retrieved from http://ugspace.ug.edu.gh

[23] Onipede, MA and Bolaji, BO (2004). Management and disposal of industrial wastes in Nigeria. Nigerian Journal of Mechanical Engineering. 2, 1, 49-63

[24]Eleje, E. O., Anienwelu, P. C. \& Adebayo, G. A. (2017). Financial and economic implications of solid waste management in Nigeria. JORIND 15(1), 330-340. www.transcampus.org/journal; www.ajol.info/journals/jorind

[25] Abdullahi, M., Ajibike, A., Man-Ugwueje, P., \& Ndububa, O. I. (2014). Environmental Impact of Indiscriminate Waste Disposal, A Case Study of Nigerian Airforce Base Kaduna, International Journal of Engineering and Applied Sciences (IJEAS), 1(1).

[26] Momodu, N. S., Dimuna, K. O., \& Dimuna, J. E. (2011). Mitigating the Impact of Solid Wastes in Urban Centres in Nigeria. Journal of Human Ecology, 34(2), 125-133

[27] Kofoworola, O.F. (2007). Recovery and recycling practices in municipal solid waste management in Lagos, Nigeria. Waste Management 27, 1139-1143

[28] Angaye, T. C. N. \& Abowei, J. F. N. (2017). Review on the environmental impacts of municipal solid waste in Nigeria: Challenges and prospects. Greener Journal of Environment Management and Public Safety, 6(2), 018-033. DOI: http://doi.org/10.15580/GJEMPS.2017.2.062117079

[29] Asikhia, M.O. \& Olaye, D. (2011). Solid waste management in Benin City: An appraisal. The Nigerian Journal of Research and Production, 18(2), 1-9

[30] Ezeah .C.(2010): Analysis of Barriers and Success factors affecting the adoption of sustainable management of municipal solid waste in Abuja, Nigeria. A PhD thesis submitted to University of Wolverhampton.

[31] Ogu, V.I. (2000). Private sector participation and municipal waste management in Benin City, Nigeria. Environmental and Urbanization, 12 (2), 103-117.

[32] Mowoe, K.M. (1990). Quality of life and Environmental Pollution and Protection in Omotola J.A (ed.), Environmental Law in Nigeria, Faculty of Law, University of Lagos, 177. 